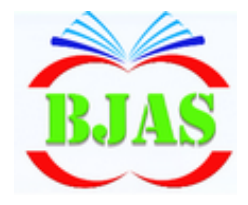

ISSN 1814- 5868
Available online at http://bjas.bajas.edu.iq

https://doi.org/10.37077/25200860.2020.33.2.02

College of Agriculture, University of Basrah

Basrah J. Agric. Sci. 33(2): 14-27, 2020
Basrah Journal of Agricultural Sciences

E-ISSN: 2520-0860

\title{
Conditions for Choosing Form of Rest Agritourism from the Point of View of Respondents in Poland
}

\author{
Michał Roman ${ }^{1 *}, M^{2}$ artyna Gontarczyk ${ }^{2}$, Monika Roman $^{3}$, Robert Kosiński² \\ \& Piotr Grudzień ${ }^{2}$ \\ ${ }^{1}$ Institute of Economics and Finance, Department of Tourism, Social Communication and \\ Counselling, Warsaw University of Life Sciences (WULS), Poland \\ ${ }^{2}$ Students' Scientific Association Public Relations, Warsaw University of Life Sciences (WULS), \\ Poland \\ ${ }^{3}$ Institute of Economics and Finance, Department of Logistics, Warsaw University of Life Sciences \\ (WULS), Poland \\ *Corresponding author: michal_roman@sggw.edu.pl
}

Received 22 April 2020; Accepted 5 July 2020; Available online 21 August 2020

\begin{abstract}
The purpose of the study was to present the factors conditioning the use of agritourism services by the respondents. The study was conducted in May 2019 using a diagnostic survey using a questionnaire on a sample of 120 randomly selected residents of Warsaw in Poland. The most frequently studied people using agritourism services for several days spending their stay connected with the family. The main motive for choosing the place of rest by the respondents was peace and quiet, as well as price attractiveness. Popular surveyed people spend their free time in agritourism services on walking and hiking and exploring the nearby area.
\end{abstract}

Key words: Rural tourism, Agritourism, Conditions, Leisure, Rural areas.

\section{Introduction}

Modern people live in a dynamic, everchanging reality that generates change and stress every day (Che et al., 2005). The increase in the pace of life and the intensification of the effects of stressful situations means that more and more recognition is enjoyed by rest in the countryside (Roman et al., 2020). The most important trump card services are clean air, close contact with nature, high landscape values, as well as the possibility of communing with friendly people and learning about their habits (Bagi \& Reeder, 2012). The advantages of relaxing away from large online cities, that agritourism enjoys the interest of tourists (Roman \& Golnik, 2019). Services that have many years of tradition both in Poland and in other international companies. In Poland, they popular after 1989, when the farming economy collapsed and many people living in the countryside had to find another source of income (Młynarczyk, 2002). Poland is a country especially predestined for the development of this type of tourism - the villages are characterized by the attractiveness of areas, traditions, folk art and interesting architectural monuments (Firlej, 2002). 


\section{Purpose and problem}

The purpose of the study was to present the factors conditioning the use of agritourism services by the surveyed residents of Warsaw. Many people living in the capital do not have contact with the village on a daily basis because they are in the urban area all the time. Investigating their opinions on agritourism as a form of recreation has allowed the determination of the strengths and weaknesses of agritourism. The problem of the article is to present the low level of agritourism development in many regions of Poland. The problem can be solved by making the offer of agritourism farms more attractive (e.g. introducing innovations). As a result, there will be a greater selection of agritourism farms by tourists, e.g. from Warsaw or other cities.

\section{Literature review: The state of agritourism development in Poland}

The concept of agritourism appeared in Polish and foreign literature at the end of the 20th century (Roman, 2019). The term was created from the combination of the prefix 'agro-' with the word 'tourism'. "Agro" comes from the Greek term agros, meaning "field" and agronomos, referring to the management of agricultural property. Tourism is a kind of active rest outside the place of residence, inspired by, among others leisure and recreational needs, as well as cognitive, cultural, social, sports, etc., including all forms of voluntary change of residence (Sznajder \& Przezbórska, 2006).

In general, and sometimes also in the literature on the subject, agritourism is often equated with rural tourism. These concepts have a lot in common, but they are not synonymous (Wojcieszak \& Sadowski, 2019). In scientific studies, a lot of space is devoted to distinguishing between these two forms of tourism, and the authors of studies mostly point out that they cannot be treated interchangeably (Roman \& Niedziółka, 2017). The term 'rural tourism' includes 'all tourism economy taking place in rural areas' (Wiatrak, 1996). In this definition, the emphasis is on the economic dimension of this form of recreation and its supply side. As a supplement, one can also refer to the explanation of the concept of "rural tourism" proposed by Sikora (1999), according to which "tourism in rural areas includes all tourism organized in the countryside", and its main purpose is "to contrast the activities and tourist conditions of the rural environment with the urban". Agritourism is a more specific subset of rural tourism (Wojcieszak, 2017). The biggest difference are the place where tourism takes place and available attractions. Any practice developed on a working farm with the purpose of attracting visitors can be named agritourism (Barbieri \& Mshenga, 2008). Also, it is believed that the hosting house should be integrated into an agricultural estate, inhabited by the proprietor and visitors should have access to take part in agricultural or complementary activities on the property (Marques, 2006).

Agritourism farms operate throughout almost all of Poland because as Drzewiecki (2009) reports- "agritourism can develop anywhere where there are no natural and anthropogenic exclusion or limiting factors". Not everywhere, however, optimal conditions for its development can be noted.

Based on the research carried out by Drzewiecki (2005), seven regions of agritourism development were distinguished: West Pomerania and Gdańsk along with the coast, Warmia and Masuria, Greater Poland, Sudetes, the Carpathians, Lublin Upland and Podlaskie. In turn, Wojciechowska (2009) 
proposed the division of the country into 12 regions distinguished by agritourism, including: the coastal region, Pomeranian region, Kashubian-Masurian-Suwałki region, Masovian region, Greater Poland region, Łódź region, West, Świętokrzyskie region, Lesser Poland region, East, Sudetes region and Podkarpackie region.

In the above-mentioned areas running agritourism farms is the most profitable. In most cases, agritourism supplements the basic agricultural activity, however, for the owners of about every tenth resort, it is the main source of income. As reported by Matlegiewicz (2015) in 2015, for $40 \%$ of people offering agritourism services their profits make up from 30 to $80 \%$ of total income. The number of agritourism farms in the years 1996-2014 is shown in table (1).

Table (1): Number of agritourism farms in Poland in the years 1996-2014*.

\begin{tabular}{cccccccccccc}
\hline Year & 1996 & 2000 & 2005 & 2007 & 2008 & 2009 & 2010 & 2011 & 2012 & 2013 & 2014 \\
\hline $\begin{array}{c}\text { Number of } \\
\text { agritourism farms } \\
\text { in Poland }\end{array}$ & 3000 & 5789 & 6550 & 8790 & 9500 & 10200 & 7692 & 7852 & 7930 & 7953 & 8200 \\
\hline
\end{tabular}

* (Matlegiewicz, 2015).

Analysis of the data presented in table (1) shows that the number of agritourism farms has changed over the years. From 1996, when there were only 3,000 of them all over Poland, it increased systematically until 2009 to reach a record number of 10200 farms in the last of these years. However, this trend changed in 2010, when the number of centers from 10200 recorded in 2009 dropped to

The statistical data of the Central Statistical Office shows that the owners of agritourism farms in 2016 provided tourists with 507800 beds. However, from the data of the Central Statistical Office in April 2018, it appears that in 2017 they granted such places 537,000, i.e. 30 more (Wykorzystanie, 2017).

From the fluctuations in the number of farms and beds offered by service providers, The study was conducted in May 2019 using a diagnostic survey using a questionnaire on a sample of 154 randomly selected residents of Warsaw. Then qualified were people who at least once used this form of recreation in rural
7,692 the following year. Since then, however, the popularity of agritourism services has been increasing again, although the number of farms has been growing very slowly every year. According to data, in 2014 there were 8,200 farms providing agritourism services. In 2015, this number dropped to 7700 (Data from the Central Statistical Office, 2020).

agritourism is not an easy form of service to run. It requires time and appropriate skills, and in addition farm owners should meet the growing demands of customers, hence only farmers who can adapt to the expectations of tourists can survive in this activity. For this reason, the number of agritourism farms in Poland is constantly changing.

\section{Methods}

areas- a total of 120 people. The characteristics of the studied population are presented in table (2). 
Roman et al. / Basrah J. Agric. Sci., 33(2): 14-27, 2020

The majority of respondents were women. The majority of respondents were people under 34 years of age who had secondary or higher education. The following conditions have been included in the empirical studies: the frequency of using agritourism services, length of stay and accompanying persons during rest on agritourism farms, motives for using agritourism services, forms of spending free time on agritourism farms, strengths and weaknesses of agritourism services in the respondents' opinion.

Table (2): The characteristics of the studied population.

\begin{tabular}{|c|c|c|c|}
\hline & Specification & $\mathrm{N}=120$ & $\%$ \\
\hline \multirow{2}{*}{ Gender } & Woman & 86 & 71.7 \\
\hline & Man & 34 & 28.3 \\
\hline \multirow{4}{*}{ Age } & Up to 24 years old & 44 & 36.7 \\
\hline & $25-34$ & 62 & 51.7 \\
\hline & $35-44$ & 10 & 8.3 \\
\hline & Over 45 years old & 4 & 3.3 \\
\hline \multirow{4}{*}{ Education } & Elementary & 2 & 1.7 \\
\hline & Basic vocational & 12 & 10.0 \\
\hline & Secondary & 56 & 46.7 \\
\hline & Higher & 50 & 41.7 \\
\hline
\end{tabular}

\section{Results}

The first issue taken up in the research was the frequency of using agritourism services by respondents. Stay and rest in rural areas is a popular form of tourism. Tourists more and more often appreciate the natural and cultural values of Poland, which can guarantee a pleasant holiday. That is why more and more people choose trips to agritourism farms. table (3) presents the frequency of using agritourism services by respondents, including tourist seasons (own and other authors' research). The conducted own research shows that the majority of respondents used the services of agritourism farms 2 to 3 times. On this basis, it can be concluded that the respondents relatively often used tourist trips while choosing rural areas. The results of studies by other authors show that respondents preferred one longer trip to agritourism farms in a given year in the summer.

An important factor in the research was the length of stay and accompanying persons during rest on agritourism farms. The respondents who preferred trips to agritourism farms had other predispositions, taking into account the place of rest, the form of accommodation, accompanying persons during the trip, as well as the length of stay. Detailed research results regarding the choice of location during agritourism trips are presented in table (4). 
Roman et al. / Basrah J. Agric. Sci., 33(2): 14-27, 2020

Table (3): Frequency of using agritourism services within 2-3 years by respondents, including tourist seasons $(\%)$.

\begin{tabular}{|c|c|c|c|c|c|}
\hline Specification & $\begin{array}{c}2015^{\mathrm{a}} \\
\mathrm{N}=100\end{array}$ & $\begin{array}{c}2015^{b} \\
N=108\end{array}$ & $\begin{array}{l}2016^{c} \\
N=200\end{array}$ & $\begin{array}{l}2019^{d} \\
N=120\end{array}$ & Mean \pm SD \\
\hline Rare (once every few years) & 5.0 & 34.0 & 26.0 & - & $21.7 \pm 12.2$ \\
\hline $\begin{array}{l}\text { Once a year longer trip (in the } \\
\text { summer season) }\end{array}$ & 46.0 & 38.0 & 65.0 & 11.7 & $40.2 \pm 19.1$ \\
\hline $\begin{array}{l}2 \text { to } 3 \text { times a year (shorter trips } \\
\text { in the summer season) }\end{array}$ & 49.0 & 21.0 & 9.0 & 40.0 & $29.8 \pm 15.7$ \\
\hline $\begin{array}{l}3 \text { to } 5 \text { times a year (in summer } \\
\text { and winter season) }\end{array}$ & 49.0 & 7.0 & 9.0 & 25.8 & $22.7 \pm 16.8$ \\
\hline $\begin{array}{l}\text { More than } 5 \text { times a year (in } \\
\text { summer and winter season) }\end{array}$ & 49.0 & 7.0 & 9.0 & 21.7 & $21.7 \pm 16.7$ \\
\hline
\end{tabular}

a (Dominik, 2015), ${ }^{\mathrm{b}}$ (Hawlena, et al., 2017), ${ }^{\mathrm{c}}$ (Szczepanowska \& Witkowska, 2016), d Present data.

Table (4): Choosing a place to stay during agritourism trips (\%).

\begin{tabular}{lccc}
\hline \multicolumn{1}{c}{ Specification } & $\begin{array}{c}2016^{\mathrm{a}} \\
\mathrm{N}=200\end{array}$ & $\begin{array}{c}2019^{\mathrm{b}} \\
\mathrm{N}=120\end{array}$ & $\begin{array}{c}\text { Standard } \\
\text { deviation }\end{array}$ \\
\hline I always choose the same agritourism farm & 44.0 & 11.7 & 16.2 \\
\hline I always try to choose another object for rest & 26.0 & 47.5 & 10.8 \\
\hline It depends on many factors; it can be different & 28.0 & 40.0 & 6.0 \\
\hline
\end{tabular}

a (Szczepanowska \& Witkowska, 2016) (Values do not add up to $100 \%),{ }^{\text {b }}$ Present data.

Table (5): The length of stay of respondents on agritourism farms (\%).

\begin{tabular}{lcccccc}
\hline Specification & $\begin{array}{c}2012^{\mathrm{a}} \\
\mathrm{N}=100\end{array}$ & $\begin{array}{c}2015^{\mathrm{b}} \\
\mathrm{N}=108\end{array}$ & $\begin{array}{c}2016^{\mathrm{c}} \\
\mathrm{N}=200\end{array}$ & $\begin{array}{c}2017^{\mathrm{d}} \\
\mathrm{N}=100\end{array}$ & $\begin{array}{c}2019^{\mathrm{e}} \\
\mathrm{N}=120\end{array}$ & $\begin{array}{c}\text { Standard } \\
\text { deviation }\end{array}$ \\
\hline $\begin{array}{l}\text { From 1 to 3 days (e.g. } \\
\text { weekend or holiday trip) }\end{array}$ & 72.0 & 28.0 & 18.0 & 36.0 & 35.8 & 18.2 \\
\hline From 4 to 7 days & 10.0 & 43.0 & 24.0 & 29.0 & 57.5 & 16.3 \\
\hline From 8 to 14 days & 18.0 & 23.0 & 47.0 & 19.0 & 4.2 & 13.9 \\
\hline
\end{tabular}


Roman et al. / Basrah J. Agric. Sci., 33(2): 14-27, 2020

\begin{tabular}{lllllll}
\hline Over 14 days & 18.0 & 6.0 & 10.0 & 16.0 & 1.7 & 5.3 \\
\hline
\end{tabular}

a(Sokół, 2012), ${ }^{\mathrm{b}}$ (Hawlena et al., 2017), ${ }^{\mathrm{c}}$ (Szczepanowska \& Witkowska, 2016) (Values do not add up to 100\%).

d(Dąbrowski et al., 2018), ${ }^{\mathrm{e}}$ Present data .

According to own research, almost $60 \%$ of respondents spent their time on agritourism farms from 4 to 7 days. The smallest number of respondents went up to two weeks or above this time. The results of studies by other authors show that the majority of respondents preferred to relax for up to 7 days on agritourism farms. Only the Szczepanowska \& Witkowska (2016) studies show that the surveyed people preferred to rest in rural areas for 8 to 14 days.
Own research shows that almost half of the respondents have always chosen another agritourism farm as a place to rest. The research of Szczepanowska \& Witkowska (2016) shows that almost half of the respondents preferred to choose the same object for rest all the time. Table (5) presents the length of stay of respondents on agritourism farms. Table (6) presents accompanying persons during the organization of joint trips to agritourism farms.

Table (6): People accompanying tourists during the organization of joint trips to agritourism farms in the respondents' opinion (\%).

\begin{tabular}{lcccccc}
\hline \multicolumn{1}{c}{ Specification } & $\begin{array}{c}2010^{\mathrm{a}} \\
\mathrm{N}=256\end{array}$ & $\begin{array}{c}2013-2015^{\mathrm{b}} \\
\mathrm{N}=221\end{array}$ & $\begin{array}{c}2016^{\mathrm{c}} \\
\mathrm{N}=342\end{array}$ & $\begin{array}{c}2017^{\mathrm{d}} \\
\mathrm{N}=100\end{array}$ & $\begin{array}{c}2019^{\mathrm{e}} \\
\mathrm{N}=120\end{array}$ & $\begin{array}{c}\text { Standard } \\
\text { deviation }\end{array}$ \\
\hline $\begin{array}{l}\text { With family (families } \\
\text { with children) }\end{array}$ & 76.2 & 70.6 & 24.0 & 64.0 & 45.8 & 19.0 \\
\hline $\begin{array}{l}\text { Among friends / friends } \\
\text { (organized groups) }\end{array}$ & 16.4 & 31.2 & 10.0 & 33.0 & 31.7 & 9.4 \\
\hline $\begin{array}{l}\text { With a partner } \\
\text { Grandparents with }\end{array}$ & 37.5 & 39.8 & 44.0 & - & 15.8 & 10.9 \\
\hline grandchildren & 10.9 & 13.1 & - & - & - & 1.1 \\
\hline Other & 2.0 & - & 22.0 & 3.0 & 4.2 & 8.2 \\
\hline
\end{tabular}

${ }^{\mathrm{a}}\left(\right.$ Roman, 2014), ${ }^{\mathrm{b}}\left(\right.$ Roman, 2018), ${ }^{\mathrm{c}}$ (Kosmaczewska, 2016), ${ }^{\mathrm{d}}\left(\right.$ Dąbrowski, et al., 2018), ${ }^{\text {e }}$ Present data.

The presented data shows that the surveyed respondents chose different forms of association during their stay on agritourism farms. These people preferred to travel mainly with family. Every third respondent went among friends. Research results of other authors show a similar sentence on a given topic. Only studies by Szczepanowska \&
Witkowska (2016) show that nearly half of the respondents most often went to this type of facilities with a partner.

An important factor conditioning the stay in rural areas are the motives for using agritourism services. Increasingly, an important factor that guides a tourist when 
choosing a stay is the destination of rest, where it will be possible to relax, regenerate strength in the fresh air, meet new people and their traditions and culture away from the big city in peace and quiet. Table (7) presents the motives influencing the choice of agritourism farm.

Table (7) shows, the conducted own research, as well as that of other authors, shows that the majority of respondents indicated peace and quiet as the main motive for choosing rest. Many people are tired of "big cities", which is why they are looking for peace and quiet, taking advantage of natural and cultural values. In addition, the price attractiveness of such services was an important factor. The respondents also wanted to learn about rural life, customs and customs (monuments, folk rites, folklore), as well as make new friends. The research also shows that people were guided by the popularity of the resting place they had checked. Only research by Dąbrowski et al. (2018) show that the main motive was close contact with nature.

Table (7): Motives influencing the choice of agritourism services in the opinion of the respondents $(\%)$.

\begin{tabular}{|c|c|c|c|c|c|c|}
\hline Specification & $\begin{array}{l}2010^{\mathrm{a}} \\
\mathrm{N}=221\end{array}$ & $\begin{array}{c}2012^{b} \\
N=100\end{array}$ & $\begin{array}{l}2013-2015^{c} \\
N=192\end{array}$ & $\begin{array}{l}2017^{\mathrm{d}} \\
\mathrm{N}=100\end{array}$ & $\begin{array}{c}2019^{\mathrm{e}} \\
\mathrm{N}=120\end{array}$ & $\begin{array}{l}\text { Standard } \\
\text { deviation }\end{array}$ \\
\hline Peace and quiet & 78.8 & - & 81.3 & 7.0 & 85.0 & 32.4 \\
\hline $\begin{array}{l}\text { Affordable prices, low cost } \\
\text { of holidays }\end{array}$ & 50.4 & 40.0 & 24.0 & 18.0 & 51.7 & 13.7 \\
\hline $\begin{array}{l}\text { The opportunity to meet } \\
\text { rural life, new people, habits } \\
\text { and customs }\end{array}$ & 11.5 & - & 12.5 & 17.0 & 25.8 & 5.6 \\
\hline $\begin{array}{l}\text { Close contact with nature } \\
\text { (environmental cleanliness) } \\
\text { natural and cultural values }\end{array}$ & 49.6 & 31.0 & 37.5 & 21.0 & 20.0 & 11.0 \\
\hline $\begin{array}{l}\text { Willingness to spend free } \\
\text { time actively (e.g. horse } \\
\text { riding, mushroom picking, } \\
\text { bathing in the river, etc.) }\end{array}$ & 20.4 & - & 14.6 & 10.0 & 10.8 & 4.1 \\
\hline Healthy organic food & 13.3 & 2.0 & 36.5 & 19.0 & 17.5 & 11.1 \\
\hline $\begin{array}{l}\text { Popularity of the place } \\
\text { (checked object) }\end{array}$ & 36.3 & 3.0 & - & - & 10.0 & 14.3 \\
\hline Other & 4.4 & 24.0 & - & 8.0 & - & 8.5 \\
\hline
\end{tabular}

The respondent could indicate more than one answer.

a(Roman, 2014), ${ }^{\mathrm{b}}$ (Sokół, 2012), ${ }^{\mathrm{c}}$ (Roman, 2018), d(Dąbrowski et al., 2018), ${ }^{\text {e }}$ Present data. 
To the important conditions for choosing agritourism as a form of recreation is the tourist offer, which can ensure the attractiveness of spending free time. Every tourist who comes to agritourism farms takes into account different forms of spending their time depending on individual interests and preferences. Often, such trips allow you to learn more about life in the countryside, and also acquire new skills, e.g. participation in folk handicraft workshops. This can affect regeneration and relax and rest from daily duties.

Table (8) presents the preferences for the use of free time by respondents on an agritourism farm. According to own research shows that the majority of respondents preferred to spend their free time on walking and hiking. In addition, during such trips people visited the nearby area, used the surrounding rivers, lakes (swimming, water sports, canoeing), as well as organized a bonfire or barbecue. It can be seen that the respondents most often chose those forms of recreation that do not require the need for additional equipment, often specialized (cycling, fishing). Table (9) presents the forms of gastronomy on an agritourism farm. The own research, as well as of other authors, shows that the majority of respondents used the catering services of the facility's owner or prepared meals themselves. Every fifth respondent dined at nearby gastronomy points.

Table (8): Activities and accompanying services during organization of free time in an agritourism farm $(\%)$.

\begin{tabular}{lccc}
\hline \multicolumn{1}{c}{ Specification } & $2010^{*}$ & $2019 * *$ & Standard \\
& $\mathrm{N}=256$ & $\mathrm{~N}=120$ & deviation \\
\hline Walking, hiking, including hiking trails & 63.7 & 83.3 & 9.8 \\
\hline Sightseeing in the immediate area & - & 67.5 & - \\
\hline Swimming, water sports (e.g. canoeing) & 45.1 & 55.8 & 5.3 \\
\hline Cycling & 62.8 & 54.2 & 4.3 \\
\hline Fishing & 39.5 & 14.2 & 12.7 \\
\hline Grilling, bonfire & 85.2 & 11.7 & 36.8 \\
\hline Mushrooming & 51.6 & 10.8 & 20.4 \\
\hline Traditional handicraft workshops (e.g. pottery) & - & 7.5 & - \\
\hline Horse Riding & 16.8 & 6.7 & 5.1 \\
\hline Fishing equipment rental & 42.6 & 2.5 & 20.1 \\
\hline Other & 4.7 & 1.7 & 1.5 \\
\hline
\end{tabular}

The respondent could indicate more than one answer. 
Roman et al. / Basrah J. Agric. Sci., 33(2): 14-27, 2020

*(Roman, 2014), ** present data.

Table (9): Forms of gastronomy on agritourism farms in the respondents' opinion (\%).

\begin{tabular}{lccccc}
\hline \multicolumn{1}{c}{ Specification } & $\begin{array}{c}2010^{\mathrm{a}} \\
\mathrm{N}=226\end{array}$ & $\begin{array}{c}2015^{\mathrm{b}} \\
\mathrm{N}=100\end{array}$ & $\begin{array}{c}2016^{\mathrm{c}} \\
\mathrm{N}=200\end{array}$ & $\begin{array}{c}2019^{\mathrm{d}} \\
\mathrm{N}=120\end{array}$ & $\begin{array}{c}\text { Standard } \\
\text { deviation }\end{array}$ \\
\hline I eat at the hosts & 56.6 & 61.0 & $>70.0$ & 33.3 & 12.2 \\
\hline $\begin{array}{l}\text { I prepare my own meals in the } \\
\text { facility }\end{array}$ & 33.3 & 9.0 & 4.0 & 31.7 & 13.1 \\
\hline $\begin{array}{l}\text { I use the services of small eateries in } \\
\text { nearby towns }\end{array}$ & - & 16.0 & 7.0 & 20.0 & 5.4 \\
\hline $\begin{array}{l}\text { I go to restaurants to cities or small } \\
\text { towns }\end{array}$ & - & 14.0 & - & 14.2 & 0.1 \\
\hline
\end{tabular}

a(Roman, 2014), ${ }^{\mathrm{b}}$ (Dominik, 2015), ${ }^{\mathrm{c}}$ (Szczepanowska \& Witkowska, 2016), ${ }^{\mathrm{d}}$ Present data .

The conducted own research shows that the majority of respondents (72\%) positively assessed their experiences related to agritourism services, and only for $6 \%$ of respondents such trips were negative. Other people could not express their opinion clearly. The last part of the research was to identify the strengths and weaknesses of agritourism services. Each tourist has an individual approach to choosing a given place and may have different expectations before using a given service. Table (10) presents the strengths of agritourism in the respondents' opinion.

Table (10): Strengths of agritourism in the opinion of respondents (\%).

\begin{tabular}{ll}
\hline \multicolumn{1}{l}{ Specification } & $2019(\mathrm{~N}=120)$ \\
\hline Quiet and peaceful place & 25.8 \\
\hline Affordable prices & 24.2 \\
\hline Contact with nature & 15.8 \\
\hline Nice family atmosphere & 14.2 \\
\hline Contact with farm animals & 10.0 \\
\hline Possibility to try regional products & 7.5 \\
\hline Contact with rural folklore & 2.5 \\
\hline Possibility to accompany the hosts with daily activities & 1.7 \\
\hline Other & 0.8 \\
\hline
\end{tabular}


Among the surveyed people, the strengths of agritourism include silence and peace, a diverse cuisine, a wide range of activities and opportunities for active leisure, a friendly family atmosphere on the part of the owners and a sense of comfort, as well as a combination of agritourism with everyday life in the countryside. Therefore, it can be assumed that the surveyed Warsaw residents, working professionally, were looking for cheap places where they could rest and relax. What they most appreciated during their stay at the agritourism farm was the fact that they come away from work, school and everyday duties.

The weaknesses of agritourism may result from the lack of an offer to potential customer segments. Detailed data is presented in table (11).

More than half of the respondents said that most often the offers of agritourism farms lacked activities during bad weather conditions. In addition, the lack of recreational equipment rentals, the lack of tours organized by the hosts to attractive places in the area, and the lack of activities for children was a major impediment to recreation. The research shows that the respondents wanted additional activities that meant that they would not be bored and would feel satisfied even in bad weather conditions.

Table (11): Weaknesses of agritourism in the opinion of respondents (\%).

\begin{tabular}{lc}
\multicolumn{1}{c}{ Specification } & $2019(\mathrm{~N}=120)$ \\
\hline No activities during bad weather & 55.8 \\
\hline There are no sports and recreational equipment rentals & 21.7 \\
\hline No tours organized by the hosts & 15.8 \\
\hline No regional dishes & 14.2 \\
\hline No activities for children & 7.5 \\
\hline Other & 4.2 \\
\hline
\end{tabular}

Table (12) presents the respondents opinion on the popularity of agritourism. Over half of the respondents said that agritourism is becoming an increasingly popular form of recreation. On this basis, it can be concluded that agritourism is growing in popularity in Poland. 
Table (12): The popularity of agritourism in Poland in the opinion of respondents [\%]

\begin{tabular}{|c|c|}
\hline Specification & $\begin{array}{c}2019 \\
\mathrm{~N}=120\end{array}$ \\
\hline Definitely yes & 17.5 \\
\hline Rather yes & 54.2 \\
\hline Hard to say & 15.0 \\
\hline Rather no & 7.5 \\
\hline Definitely no & 5.0 \\
\hline
\end{tabular}

\section{Conclusions}

The dynamic development of agritourism in Poland is associated with a growing demand for rest in the bosom of nature, away from the bustle of a big city, surrounded by nature and in the company of friendly people who can enrich the life experience and knowledge of tourists with stories of traditions and customs that have already been forgotten in cities. New agritourism farms are still being created, which are dynamically developing in attractive natural and cultural regions of Poland. The number of tourists enjoying this form of recreation is also increasing, and the proverbial "vacation under the pear" has ceased to be something to be ashamed of, but has even become "a fashion manifestation". Guests using agritourism services can enjoy beautiful views, enjoy the beauties of nature, taste regional cuisine, and spend their leisure time meeting new people, cultures and customs. It is also possible to combine nature relaxation with attractive forms of physical recreation by using accompanying infrastructure. Based on the own research, several conclusions were made:

Most often respondents used agritourism services for several days spending their stay together with their family, the main motive for choosing the place of rest by the respondents was peace and quiet, as well as price attractiveness, most of the respondents spent their free time on agritourism farms on walks and hikes, and exploring the surrounding area.

The article contains content on the conditions for choosing agritourism as a form of recreation. The presented issues have a significant impact on showing selected factors that stimulate the development of agritourism. There are dynamic changes in rural areas, which is why it is worth carrying out similar research on the development of agritourism in the future on a larger research sample in Poland and in selected European countries. One of the aims of the article was to compare own research with other studies.

\section{Acknowledgements}

The authors thank the respondents for participating in the research.

Conflict of interest: The authors declare that they have no conflict of interest.

\section{ORCID}

Michał Roman: 0000-0003-3596-2587

Martyna Gontarczyk: 0000-0002-1824-5941 
Roman et al. / Basrah J. Agric. Sci., 33(2): 14-27, 2020

Monika Roman: 0000-0003-1799-0445

Robert Kosiński: 0000-0001-5426-0957

Piotr Grudzień: 0000-0002-8478-7669

\section{References}

Bagi, F. \& Reeder, R.J. (2012). Factors affecting farmer participation in agritourism. Agric. Res. Econ. Rev., 41(2): 189-199. https://doi.org/10.1017/S10682805000033 48

Barbieri, C. \& Mshenga, P.M. (2008). The role of the firm and owner characteristics on the performance of agritourism farms. Sociol. Ruralis, 48, 166-183. https://doi.org/10.1111/j.14679523.2008.00450.x

Che, D.; Veeck, A. \& Veeck, G. (2005). Sustaining production and strengthening the agritourism product: Linkages among Michigan agritourism destinations. Agr. Hum. Values, 22(2): 225-234. https://doi.org/10.1007/s 10460-004-82820

Data from the Central Statistical Office in Warsaw Poland (2020). https://stat.gov.pl [state as of day 10.03.2020].

Dąbrowski, D.; Sokół, J.L.; Bieniek, M. \& Radwańska, K. (2018). [Prospects for the development of rural tourism in the Sławatycze commune in the Lublin voivodeship]. Rynek-SpołeczeństwoKultura, 4(30): 122-127. (In Polish).https://kwartalnikrsk.pl/assets/rsk4-2018-dabrowski-radwanska-sokolbieniek-perspektywy-rozwoju-turystykiwiejskiej-na-obszarze-gminyslawatycze.pdf

Dominik, P. (2015). [Cultural and nutritional importance of bread in agritourism]. Turystyka Kulturowa, 12: 51-66. (In
Polish).

http://yadda.icm.edu.pl/yadda/element/bw meta1.element.desklight-774f6c0d-f8dc4d95-bf23-3ee284b3de13/c/671-2180-1PB_pieczywo.pdf

Drzewiecki, M. (2005). [Agritourism in Poland- Current State and Development Trends. 46-51 In: Sawicki, B. \& Bergier, J. (Eds.). Conditions for the Development of Tourism Related to Rural Areas.] Biała Podlaska: Wydawnictwo Państwowa Wyższa Szkoła Zawodowa im. Jana Pawła II w Białej Podlaskiej): 180pp. (In Polish).

Drzewiecki, M. (2009). [Contemporary agritourism in Poland]. Gdańsk: Wydawnictwo Wyższej Szkoły Turystyki i Hotelarstwa w Gdańsku. 88pp. (In Polish).

Firlej, K. (2002). [The Condition and Development Possibilities of Agritourism in Poland]. Kraków: Wydawnictwo Instytutu Spraw Publicznych Uniwersytetu Jagiellońskiego. 25pp. https://depot.ceon.pl/bitstream/handle/123 456789/6817/Stan\%20i\%20mo\%20liwo\% 20ci\%20rozwoju\%20agroturystyki\%20w $\% 20$ Polsce.pdf?sequence $=1$ (in Polish)

Hawlena, J.; Surdacka, E. \& Pieniążek, M. (2017). [The impact of agritourism on the change of the economic model of functioning of rural farms in the Świętokrzyskie province]. Autobusy: Technika, Eksploatacja, systemy transportowe, 6: 1678-1685. (In Polish).http://yadda.icm.edu.pl/yadda/ele ment/bwmeta1.element.baztech-d9ae8f2f63ef-4603-bbc193a4b56f916d/c/323_342_OiZ_HAWLE NA_SURDACKA_PIENIAZEK.pdf 
Roman et al. / Basrah J. Agric. Sci., 33(2): 14-27, 2020

Kosmaczewska, J. (2016). [Analysis of online consumer reviews on the example of selected agritourism farms. 183-193. In: Jęczmyk, A.; Uglis, J. \& Maćkowiak, M. (Eds.). Rural Tourism. Economic and marketing issues]. Poznań: Wydawnictwo Wieś Jutra Sp. zo.o., Poznań. 202pp. (In Polish).

http://www1.up.poznan.pl/ktw/sites/defaul t/files/dokumenty/Turystyka_wiejska_tom _1.pdf

Marques, H. (2006). Searching for complementarities between agriculture and tourism- the demarcated wineproducing regions of northern Portugal. Tourism Econ., 12: 147-155. https://doi.org/10.5367\%2F000000006776 387141

Matlegiewicz, M. (2015). [Agritourism - nonagricultural business of the Polish countryside]. Ekonomia i Środowisko, 4: 221-234. (In Polish). http://www.ekonomiaisrodowisko.pl/uplo ads/eis\%2055\%20pliki/17\%20matlegiewi cz.pdf

Młynarczyk, K. (2002). [Agritourism]. Olsztyn: Wydawnictwo Naukowe Uniwersytetu Warmińsko-Mazurskiego. 236pp. (In Polish).

Roman, M. (2014). [Economic and social conditions of agritourism development in rural communes of the Podlaskie province]. Jadwigi Dziubińskiej w Golądkowie. 167pp. (In Polish). https://www.researchgate.net/profile/Mich al_Roman4

Roman, M. (2018). [Innovation of agritourism as a factor in improving the tourist competitiveness of Eastern Poland macroregion]. Warszawa: Wydawnictwo SGGW: 280pp. (In Polish)
https://www.researchgate.net/profile/Mich al_Roman4

Roman, M. (2019). Opinion of the local community on the tourist attractiveness of the commune and selected agritourism development factors. Ann. Polish Ass. Agric. Agribus. Econ., 21, 3: 390-400. http://dx.doi.org/10.5604/01.3001.0013.35 35

Roman, M. \& Golnik, B. (2019). Current status and conditions for agritourism development in the Lombardy region. Bulg. J. Agric. Sci., 25, 1: 18-25. https://www.agrojournal.org/25/01-03.pdf

Roman, M. \& Niedziółka A. (2017). [Agritourism as a Form of Entrepreneurship in Rural Areas]. Warszawa: Wydawnictwo SGGW: 120pp. https://witrynawiejska.org.pl/data/agrotur ystyka.pdf

Roman, M.; Roman, M. \& Niedziółka, A. (2020). Spatial diversity of tourism in the countries of the European Union. Sustainability, 12, 2713: 1-16. http://doi:10.3390/su12072713

Sikora, J. (1999). [Organization of tourist traffic in the countryside]. Warszawa: Wydawnictwa Szkolne i Pedagogiczne. 255pp. (In Polish).

Sokół, J.L. (2012). [The activity of agritourism farms in the Narew National Park in the opinion of tourists and their new challenges]. Ekonomia i Zarządzanie, 3: 118-128. (In Polish). http://yadda.icm.edu.pl/baztech/element/b wmeta1.element.baztech-article-BPBD00020019/c/httpwww_zneiz_pb_edu_plk wartalnik320122_2sokol.pdf

Szczepanowska, E. \& Witkowska, I. (2016). [An attempt to assess selected features of agritourism in the commune of 
Roman et al. / Basrah J. Agric. Sci., 33(2): 14-27, 2020

Złocieniec]. Roczniki Naukowe Stowarzyszenia Ekonomistów Rolnictwa i Agrobiznesu, 18: 3, 333-340. (In Polish). http://agro.icm.edu.pl/agro/element/bwme ta1.element.agro-e67266d6-417c-4291a17f-a4f7833c0618/c/18-3-

Szczepanowska.pdf

Sznajder, M. \& Przezbórska, L. (2006). [Agritourism]. Warszawa: Polskie Wydawnictwo Ekonomiczne: 300pp. (In Polish).

Wiatrak, A.P. (1996). [The impact of agritourism on rural development]. Zagadnienia Ekonomiki Rolnej, 1: 34-46. https://www.academia.edu/23834109/WP ŁYW_AGROTURYSTYKI_NA_ZAGOS PODAROWANIE_OBSZARÓW_WIEJS KICH (In Polish).

Wojciechowska, J. (2009). [Processes and Conditions for the Development of Agritourism in Poland]. Łódź: Wydawnictwo Uniwersytetu Łódzkiego: 350pp. (In Polish).
Wojcieszak, M. (2017). [Conditions for the Development of Nature Tourism in Metropolitan Areas and its Economic Effects]. Poznań: Wydawnictwo Uniwersytetu Przyrodniczego w Poznaniu: 150pp. (In Polish).https://www.researchgate.net/profi le/Monika_Wojcieszak

Wojcieszak, M. \& Sadowski, A. (2019). Geographic differentiation of agritourism activities in Poland vs. cultural and natural attractiveness of destinations at district level. PLoS ONE, 14(9): e0222576. https://doi.org/10.1371/journal.pone.0222 576

Wykorzystanie, T.O.N.W. (2017).[Year]. https://stat.gov.pl/obszarytematyczne/kultura-turystykasport/turystyka/baza-noclegowa-wedlugstanu-w-dniu-31-lipca-2017-r-i-jejwykorzystanie-w-i-polroczu-2017roku,4,14.html (Date of access 10.03.2020).

\section{شروط اختيار مكان الاستراحة في السياحة الزراعية في بولندا}

\section{مايكل رومان 1، مارتينا غونتاركزيك²، مونيكا رومان3، روبرت كوسينسكي² و بيوتر كرويزن2}

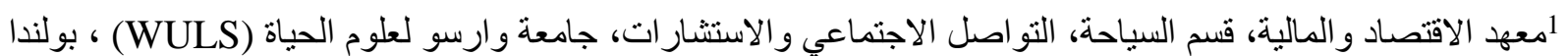

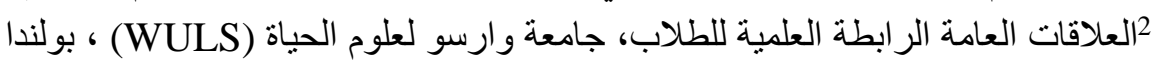

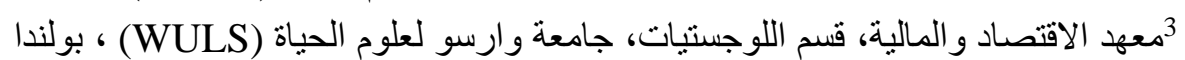

المستخلص: كان الغرض من الدراسة هو عرض العوامل المشروطة لاستخدام خدمات السياحة الزراعية. أجريت الدراسة في ايار 2019 باستخدام مسح تشخيصي باستخدام استبيان على عينة من 120 شخص عشوائياً شملهم الاستطلاع في وارسو في بولندا. الأشخاص الذين تمت دراستهم يستخدمون خدمات السياحة الزراعية لعدة أيام حين يقضون إقامتهم مع العائلة. كان الدافع الرئيسي

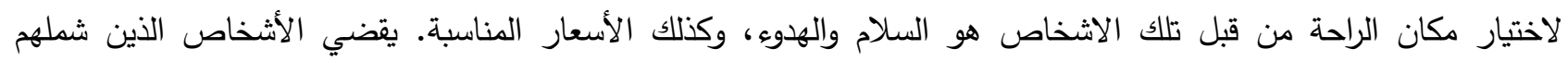
الاستطلاع وقت فراغهم في خدمات السياحة الزراعية على المشي في الاماكن العامة والمشي لمسافات طويلة في الطبيعة واستكثاف المنطقة المجاورة. الكلمات المفتاحية: السياحة الريفية، السياحة الزراعية، الظروف، أوقات الفراغ، المناطق الريفية. 